\title{
The psychometric properties of a workplace boredom scale (DUBS) within the South African context
}

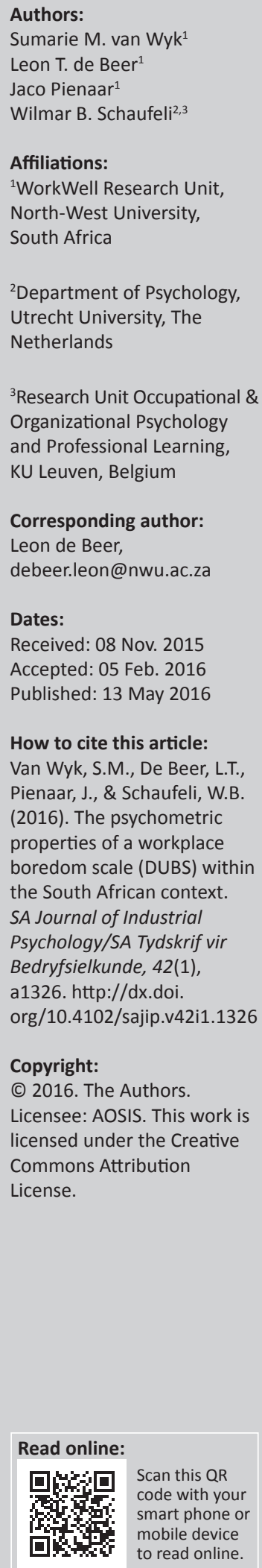

Orientation: Boredom at work has been shown to be a concern for individuals and organisations. At the time of this research, no validated scale was available to measure and investigate workplace boredom within the South African context.

Research purpose: To determine the psychometric properties of the Dutch Boredom Scale (DUBS) within the South African context.

Motivation for the study: No reliable and valid scale for workplace boredom was available in South Africa at the time of the current research. Boredom at work has been found to affect organisations negatively in other countries. Insights are needed into workplace boredom and how it affects the outcomes of organisations in South Africa.

Research design, approach and method: A cross-sectional research approach was utilised. A random convenience sample $(N=490)$ was obtained from organisations within the manufacturing and logistics sector. In order to validate the DUBS, the factor structure, construct validity (convergent and discriminant validity) and scale reliability were investigated. A mediation model was also tested with structural equation modelling to ascertain predictive validity.

Main findings: The results showed that the one-factor structure of the DUBS could be confirmed and that this factor had acceptable reliability. In terms of convergent validity, all of the item indicators loaded significantly on the workplace boredom construct, and the relationship between workplace boredom and work underload revealed that they were positively correlated with medium effect size. Furthermore, work engagement and organisational commitment were correlated negatively in terms of practical significance with workplace boredom. A structural mediation model showed that work underload was significantly and positively associated with boredom, which in turn had significant negative relations to both work engagement and organisational commitment. No significant direct relations were found from work underload to either work engagement or organisational commitment. Instead, bootstrapping showed that there was an indirect-only relationship from work underload to work engagement and organisational commitment through workplace boredom - indicating full mediation.

Practical/managerial implications: Management should not neglect workplace boredom, as results indicate that it may adversely impact work engagement and organisational commitment. Therefore, workplace boredom should be a concern not only for individuals, but also for the organisation at large.

Contribution/value-add: This study contributes to the limited research available on workplace boredom in South Africa by providing evidence of acceptable psychometric properties for a workplace boredom scale.

\section{Introduction}

Workplace boredom is a persistent phenomenon that will continue to be experienced within organisations as the increase in the educational level of employees and continuous technological advancements result in automated work practices where individuals become overqualified for repetitive and unvarying jobs (Fisher, 1993; Loukidou, Loan-Clarke \& Daniels, 2009; Martin, Sadlo \& Stew, 2006). In other words, boredom is evident where employee capability outweighs task complexity. Technological changes in addition to economic turmoil are likely to aggravate the prevalence of workplace boredom, as highly qualified workers may agree to take lower-level job positions in times of uncertainty to secure income (Sohail, Ahmad, Tanveer \& Tariq, 2012). Workplace boredom is a phenomenon that is prevalent and affects organisations and employees across various countries (Bruursema, Kessler \& Spector, 2011; Fisher, 1993; Martin et al. 2006). 
This necessitates the need for a validated scale to measure and address the occurrence of workplace boredom, within South African organisations.

Workplace boredom can be described as the experience of boredom within the context of work, where the employee feels under-challenged or under-stimulated in his or her work (Loukidou et al. 2009). The employee experiences workplace boredom as a negative emotional state and as a result tries to alleviate this discomforting feeling by engaging in non-work-related behaviours (Fisher, 1993; Loukidou et al. 2009; Mikulas \& Vodanovich, 1993). Basically, all employees are susceptible to workplace boredom. This phenomenon may manifest itself at all levels of any organisation, and the prevalence of workplace boredom is a common occurrence across various contexts (Fisher, 1993; Harju, Hakanen \& Schaufeli, 2014; Martin et al. 2006; Sundberg \& Staat, 1992). Schubert (1977) hypothesised that boredom might occasionally lead to increased creativity, which inspires a search for change and variety, but his study results were inconclusive and the assumption can be regarded as speculative. However, the vast majority of research indicates that workplace boredom negatively affects both the organisation and its employees to such an extent that the organisation's competitive advantage is affected (Kass, Vodanovich \& Callender, 2001; Meyer, 2012).

To date, there is no thorough theory on boredom, let alone workplace boredom (Fisher, 1993; Reijseger et al. 2012). Rather, the focus of research has mainly been on identifying an assortment of individual and work-related factors that can be linked with workplace boredom (Shackleton, 1981). Studies have shown that workplace boredom adversely negatively affects job satisfaction and organisational commitment, which are essential elements to the success of any organisation (Kass et al. 2001; Reijseger et al. 2012; Schaufeli \& Salanova, 2014; Wallace, Vodanovich \& Restino, 2003). Furthermore, these organisational outcomes correlate with employees' performance, productivity and intention to leave (Fisher, 1993; Markos \& Sridevi, 2010; Meyer, 2012; Wallace et al. 2003). Employees may be affected by workplace boredom to such an extent that they cannot work optimally, so that their work performance is impaired (Kass, Wallace \& Vodanovich, 2003).

Workplace boredom is considered a neglected topic on which no research has been conducted within the South African context, as no psychometrically validated workplace boredom scale was available at the time of the current research. The study on which this article reports aimed to validate the Dutch Boredom Scale (DUBS) (Reijseger et al. 2012) within the South African context in order to assist future research on the topic. The focus of the current study was to investigate the psychometric properties of the DUBS by determining the reliability and construct validity of the scale within the South African context. The results would assist in establishing the usefulness of the DUBS as a workplace boredom scale within the South African context.

\section{Literature review}

\section{Workplace boredom}

Fisher (1993) describes boredom as a fleeting unpleasant state, arising from inter alia under-stimulation, where the employee experiences a lack of interest and finds it difficult to concentrate on the present activity or situation. The essential elements of the boredom phenomenology include the individual's inability or difficulty maintaining focus and concentration (Fisher, 1993; Loukidou et al. 2009). In addition, it is associated with an unpleasant feeling, which causes the individual to search for variety in order to alleviate this negative state (Hamilton, Haier \& Buchsbaum, 1984; Loukidou et al. 2009). Workplace boredom is similar to boredom but refers to the experience of boredom as described above, contextualised within the domain of work.

Thus, workplace boredom can be defined as a task- or activityrelated, unpleasant, dissatisfying and de-activating emotion due to low arousal or the under-stimulating nature of the job (Fisher, 1993; Mikulas \& Vodanovich, 1993). Workplace boredom is a temporary state of mind where one may feel bored one moment but not the next (Fisher, 1993). However, boredom at work becomes problematic if it is experienced on a frequent basis. It differs from other affective states (e.g. work engagement) as bored employees often feel unchallenged, thus making the situation or the job seem increasingly meaningless (Van Tilburg \& Igou, 2012). Meaning encompasses sense of purpose and values that provide a sense of justification and one's sense of self-worth (Baumeister, 1991).

Some researchers on workplace boredom have attributed the cause of workplace boredom to the work situation itself (Hill \& Perkins, 1985). Traditionally, it was assumed that job characteristics such as monotony or the repetitive nature of tasks inevitably led to workplace boredom (Hill \& Perkins, 1985). However, according to Shackleton (1981), not everyone working within repetitive jobs is likely to experience workplace boredom. Research suggests that employees' appraisal of the (work) situation determines their response in terms of boredom (Lazarus, 1991; Weiss \& Cropanzano, 1996), for example, the employee's capability versus task complexity mentioned earlier. Seen from this perspective, the job characteristics and work environment are considered to be potential sources of workplace boredom (Loukidou et al. 2009). These job characteristics refer specifically to task variety, autonomy and utilisation of skills (Fisher, 1993; Loukidou et al. 2009; Smith, 1981).

\section{Measurement of boredom}

Interest in the boredom domain has led to the development of various scales in order to measure the phenomenon. However, only a single scale (the DUBS) was available that focused specifically on the employee's experience of boredom in the work environment. Earlier scales, such as the Job Boredom Scale (JBS) (Grubb, 1975; Lee, 1986), focused primarily on the antecedents of workplace boredom with reference to an under-stimulating work environment 
and excluded the affective, cognitive and behavioural manifestations of boredom itself (Vodanovich, Wallace \& Kass, 2005). Alternatively, dispositional boredom scales (Farmer \& Sundberg, 1986) (i.e. susceptibility to boredom as a personality trait such as sensation-seeking) took various boredom responses into account but did not relate these responses to the work environment. Reijseger et al. (2012) combined the strengths of both the JBS and dispositional scales to create a new scale known as the DUBS. The DUBS measures work-related boredom and focuses on the employee's affective, cognitive and behavioural responses with regard to an under-stimulating work environment.

\section{The development, validity and reliability of the DUBS}

Reijseger et al. (2012) developed the DUBS in the Netherlands. The process of developing the DUBS included construct conceptualisation, item adaption (combining of two existing boredom scales), psychometric evaluation and further refinement. The items of the DUBS were primarily aimed at measuring the experience and manifestation of workplace boredom (cf. Baker, 1992; Hill \& Perkins, 1985). An eight-item scale was designed at first. These DUBS items were adapted from the Boredom Proneness Scale (Farmer \& Sundberg, 1986) and the JBS (Grubb, 1975; Lee, 1986). The DUBS measures feelings, thoughts and behaviours (or the absence of behaviours) that are prevalent when boredom is experienced at work. These include the perception of time passing slowly and feeling bored (Hill \& Perkins, 1985), task-unrelated thoughts (Damrad-Frye \& Laird, 1989) and inclinations to engage in non-work-related activities (Baker, 1992).

Reijseger et al. (2012) used three convenience samples that included respondents from various organisational sectors. All item scores correlated significantly; hence, a unidimensional construct was apparent. Furthermore, confirmatory factor analyses (CFAs) provided the necessary evidence to confirm a one-factor structure consisting of six items. Two items were dropped from the original scale because they appeared to be ambiguous and unsound. The resulting six-item scale showed an acceptable reliability as the Cronbach's alpha indicated a high level of internal consistency $(\alpha=0.80)$ (Reijseger et al. 2012). Thus, based on previous work on the DUBS in the Netherlands, two hypotheses were formulated:

Hypothesis 1: Workplace boredom, as assessed with the DUBS, is a one-dimensional construct.

Hypothesis 2: The workplace boredom scale is reliable (i.e. Cronbach's $\alpha \geq 0.70$ ).

\section{Construct validity: Convergent validity}

The validity of a measuring instrument is considered important as this influences the precision, interpretation and usefulness of the findings (Foxcroft \& Roodt, 2009; Westen \& Rosenthal, 2003). When determining the validity of an instrument, one method is to investigate its convergent validity. Convergent validity refers to the extent to which two theoretical constructs that are expected to be related to one another are in fact related (Campbell \& Fiske, 1959). It is expected that significant correlations between the DUBS and other constructs such as work engagement (negative correlation), organisational commitment (negative correlation) and work underload (positive correlation) will be evident.

Work underload and workplace boredom: In the present study, work underload referred to the employee's perception of work in terms of reversed role overload (Beehr, Walsh \& Taber, 1976). In this context, work underload can be described as having too little work to do within a given timeframe (Larson, 2004) or having work that does not live up to the individual's competence, skills and knowledge (Fineman \& Payne, 1981; Spector \& Jex, 1998).

Due to having too little to do, or experiencing one's job as too simple and unchallenging, workplace boredom is experienced. Workplace boredom may therefore occur when quantitative 'underload' is experienced; that is, when tasks are considered to be monotonous, unchallenging or repetitive (Fisher, 1993). Thus, the expectation exists that there is a positive relationship between workplace boredom and work underload, which leads to the following:

Hypothesis 3: Workplace boredom and work underload are positively related.

Work engagement and workplace boredom: The link between workplace boredom and work engagement suggests that boredom at work impairs employee productivity and well-being (Whiteoak, 2014). Work engagement is typically described as 'a positive, fulfilling work-related state of mind that is characterised by vigour, dedication, and absorption' (Schaufeli, Salanova, Gonzalez-Romá \& Bakker, 2002, p. 74). Contrarily, bored employees experience a dissatisfying negative state, which is usually associated with negative outcomes and withdrawal from work (Bruursema, Kessler \& Spector, 2011; Game, 2007). It appears that the presence of workplace boredom decreases work engagement and vice versa (Reijseger et al. 2012). Warr and Inceoglu (2012) support the notion that work engagement is negatively related to workplace boredom, and they describe workplace boredom (an unpleasant state of passiveness) as the polar opposite of work engagement (a pleasant and activated state), in line with Warr's model of affective well-being (Warr, 1990). Similarly, Schaufeli and Salanova (2014) hypothesised and showed that work engagement is inversely related to workplace boredom. Hence, the following hypothesis is formulated:

Hypothesis 4: Workplace boredom has a negative relationship with work engagement.

Organisational commitment and workplace boredom: Although organisational commitment has affective, continuance and normative components (Allen \& Meyer, 1990; Meyer, Allen \& Smith, 1993), the focus in the current study was on the affective component. The reason is that it appears to be the most consistent commitment component that is associated with other organisational variables (cf. Meyer, Stanley, Herscovitch \& Topolnytsky, 2002). According to Allen and Meyer (1990), the affective component 
taps the employee's identification and emotional connection with the organisation as well as participation in the organisation.

When workplace boredom is prevalent, employees experience their job as dissatisfying; therefore, they are less committed to the organisation and willing to leave their jobs (Kass et al. 2001; Reijseger et al. 2012). Reijseger et al. (2012) found a negative relationship between workplace boredom and organisational commitment. This finding indicates that employees who experience workplace boredom also experience less organisational commitment - indicating a negative exchange relationship.

Hypothesis 5: Workplace boredom has a negative relationship with organisational commitment.

\section{Predictive validity: A mediation model}

Predictive validity is an alternative form of validity that can be useful in a validation study. It refers to the precision with which a measure can predict future behaviour, responses or category status (Foxcroft \& Roodt, 2009), that is, the predictive regression based on theoretical argument. Predictive validity is typically associated with a longitudinal research design, where cause and effect can be more definitively demonstrated. However, cross-sectional data allow the researcher to begin investigations of the regressions with regard to a onedirectional relationship (De Vos, Strydom, Fouché \& Delport, 2012; O'Dwyer \& Bernauer, 2014). For the purpose of this study, predictive validity was considered by means of a mediation model - see Figure 1 for a representation of this model. As argued above, work underload may result in an employee feeling under-challenged, leading to boredom and in turn to a possible decrease in work engagement and organisational commitment. Based on this reasoning, the final two hypotheses were formulated.

Hypothesis 6: Workplace boredom mediates the relationship between work underload and work engagement.

Hypothesis 7: Workplace boredom mediates the relationship between work underload and organisational commitment.

\section{The present study}

To date, no research on workplace boredom has been conducted within the South African context. South Africa is a unique multicultural nation where different cultural backgrounds, ethnicities and values are found (Foxcroft \& Roodt, 2009). The historic context of this nation and the various adversities faced (e.g. the after-effects of apartheid)

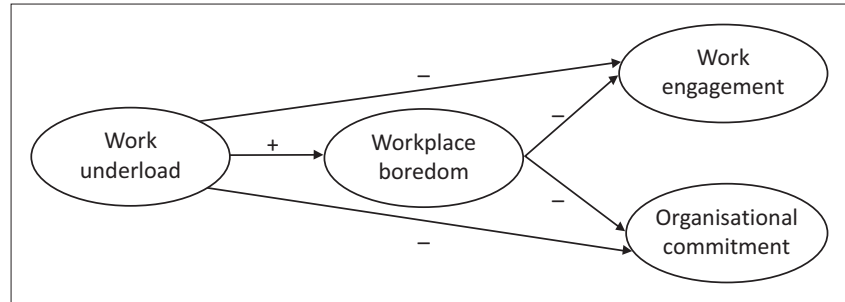

FIGURE 1: The structural model for determining direct and indirect (mediated) relationships. might affect the manner in which a psychological phenomenon is perceived (Rodrik, 2008). As a result, the values, norms and assumptions of the South African workforce could differ from those in other countries and could thus influence the experience of a phenomenon such as workplace boredom (Foxcroft \& Roodt, 2009). The suitability of utilising a measuring instrument from another country could be considered questionable, if the measuring instrument was not validated in the specific country, presenting the possibility of questionable results (Foxcroft \& Roodt, 2009). Furthermore, the Employment Equity Act (Government Gazette, 1998) prohibits the use of psychological assessment without appropriate evidence of reliability and validity within this context. Therefore, the purpose of this research was to investigate the psychometric properties of a workplace boredom measure for use within South Africa, as the first step to assist future researchers on the topic in this context.

\section{Research design Research approach}

For the purpose of this study, a quantitative research approach was used, which implies that the variables were measured in order to analyse and compare results. Quantitative research comprises large samples and data collection procedures that are structured (De Vos et al. 2012; Struwig \& Stead, 2001). This study followed a cross-sectional survey design (Du Plooy, 2002). Cross-sectional designs are useful because variables are measured simultaneously, which allows for assessing interrelationships between variables (Struwig \& Stead, 2001).

\section{Research method}

\section{Research procedure}

Permission and consent to gather data were obtained from logistic and manufacturing organisations, as well as from the individuals who participated in the survey. Hard copies of the surveys were printed and handed out to participating employees by the researcher. Each survey consisted of a cover letter explaining the purpose of the research. Emphasis was placed on anonymity, confidentiality and voluntary participation with no negative repercussions.

\section{Research participants}

The study sample consisted of a combination of participants from logistics and manufacturing organisations $(N=490)$. The mean age of participants was 39.16 (standard deviation = 11.35). About half (51\%) of the sample consisted of female participants. Participants who were married or living with a partner constituted $58 \%$ of the sample. Most of the respondents possessed a university degree (34\%), followed by a Grade 12 qualification (22\%). The number of participants who spoke Western Germanic languages was 327 (68\%), and 156 spoke an African language (31\%).

\section{Measures}

All of the items in the survey were presented in English only. The Cronbach's reliability coefficient for each scale in this 
section was based on previous studies with the scales. The Cronbach's alpha coefficients for the current study are presented in Table 3.

Workplace boredom was measured with the DUBS, developed by Reijseger et al. (2012). This one-dimensional scale for measuring workplace boredom uses a five-point rating scale ranging from 1 ('never') to 5 ('always'). Workplace boredom is measured by six items (e.g. 'I feel bored at my job' and 'I tend to do other things during my work'). The scale has a reported Cronbach's alpha coefficient of 0.80 (Reijseger et al. 2012).

Work engagement was measured in terms of items from the Utrecht Work Engagement Scale (UWES) (Schaufeli et al. 2006). This instrument typically consists of 17 items, which are all scored on a seven-point frequency-rating scale ranging from 0 ('never') to 6 ('always'). Only items from the core components of work engagement (i.e. vigour and dedication items) were used as indicators of work engagement (Langelaan, Bakker, Van Doornen \& Schaufeli, 2006). For the purposes of the current study, 11 items were used measuring vigour (e.g. 'I can continue working for very long periods at a time') and dedication (e.g. 'I find the work that I do full of meaning and purpose'). The UWES has been used in South Africa with good reliability (Storm \& Rothmann 2003).

Organisational commitment was measured using a five-point scale ranging from 1 ('strongly disagree') to 5 ('strongly agree'). This scale is based on the items of the affective organisational commitment component by Allen and Meyer (1990) and five items were used (e.g. 'I would be very happy spending the rest of my career with this organisation'). Cronbach's alpha coefficients of above 0.70 have been reported for this scale (Allen \& Meyer, 1990).

Job satisfaction was measured with the scale developed by Hellgren, Sjöberg and Sverke (1997). This three-item instrument uses a five-point scale ranging from 1 ('strongly disagree') to 5 ('strongly agree') to measure the individual's satisfaction with his or her job (e.g. 'I enjoy being at my job'). In the study by Hellgren et al. (1997), this scale reported a Cronbach's alpha coefficient of 0.86, and in South Africa an alpha of 0.80 has been shown (Pienaar, Sieberhagen \& Mostert, 2007).

Work underload a workload scale was used (Price, 2001; adapted from Kim, Price, Mueller \& Watson, 1996). One reversed item for workload was used as the first item in the factor to reverse the polarity of the factor to work underload in the CFA (e.g. 'My workload is not heavy on my job'). A five-point rating scale was used, which ranged from 1 ('strongly disagree') to 5 ('strongly agree').

\section{Statistical analysis}

Preliminary item analysis was performed in Mplus with the TYPE=BASIC function. This provided means, standard deviations, skewness, kurtosis and minimum and maximum values. Skewness and kurtosis would be considered problematic for any values below -2.00 or above 2.00 (George \& Mallery, 2010). To investigate the reliability of the constructs, Cronbach's alpha coefficients were calculated. Acceptable values for the reliability coefficients would have a lower-bound cut-off value of 0.70 (Bland \& Altman, 1997). Moreover, structural equation modelling (SEM) methods were applied with Mplus 7.31 (Muthén \& Muthén, 2014). The estimation method implemented was the maximum likelihood (ML) estimator for all analyses. Firstly, a CFA was implemented in order to investigate the factor loadings of the individual items of the latent workplace boredom variable. Secondly, a total measurement model was constituted to include all the study variables to constitute a structural model, based on latent variables, to investigate the correlations and relationships proposed in the study hypotheses. No correlation of error terms between observed indicators were forced or any parcelling strategies used. To evaluate the fit of all the models to the data, the following fit indices were considered (Cudeck \& Browne, 1993; Van de Schoot, Lugtig \& Hox, 2012):

- The comparative fit index (CFI) (values of 0.90 and above).

- The Tucker-Lewis index (TLI) (values of 0.90 and above).

- The root mean square error of approximation (RMSEA) (values smaller than 1.0, but ideally smaller than 0.08).

- The square root mean residual (SRMR) (values smaller than 0.08).

- The Bayesian information criterion (BIC) - the lowest value indicating the better model.

Discriminant validity is established when evidence can be provided that the constructs of interest in a study can be shown to not be captured by other measures in the model (Hair, Black, Babin \& Anderson, 2010). Thus, study variables should not correlate too highly and an undue influence in variation should not be evident between variables, which can distort results (e.g. $r \geq 0.85$; Brown, 2015). In this study, the method described by Fornell and Larcker (1981) is used to establish discriminant validity. This method computes the average variance extracted (AVE) and the shared variance between the constructs involved. To pass this test, the AVE of the latent constructs should be higher than the shared variance between those constructs. Therefore, workplace boredom should be sufficiently correlated with the constructs as described above $\left(\mathrm{H}_{3}-\mathrm{H}_{5}\right)$, but overlap should not be excessive and discriminant validity should exist.

The practical significance of correlation coefficients were set at 0.30 and above for a medium effect and at 0.50 and above for a large effect (Cohen, 1988). Overall statistical significance was considered at the $95 \%$ level $(p \leq 0.05)$.

To investigate the mediation model, the MODEL INDIRECT function in Mplus was used with 5000 bootstrap replications within the structural model specifications. The focus was therefore on the significance of the indirect effect and its 95\% confidence interval (Rucker, Preacher, Tormala \& Petty, 2011). Furthermore, the classification of the mediation model was 
done according to the guidelines of Zhao, Lynch and Chen (2010). Specifically, these guidelines indicate that the mediation model can be classified as an indirect-only mediation if the relationship from the independent variable to the mediator is significant and the relationship from the mediator to the outcome is also significant (synonymous to full mediation). However, if the relationship from the independent variable is also significant, the model is classified as a complementary mediation model (synonymous to partial mediation).

\section{Results}

\section{Preliminary analysis: Workplace boredom item descriptive statistics}

Table 1 shows that the participants tended to score more towards the lower end of the scale compared with the extreme end of the scale - indicating that, overall, the experience of boredom at work is less frequent, but remains present for some employees. Furthermore, the skewness and kurtosis values for all the items remained below the set cut-off point of \pm 2.00 - indicating that the data was approximately normally distributed and that normal ML was an applicable estimation method as opposed to the robust ML estimator.

\section{CFA of workplace boredom}

The CFA results showed that the one-factor measurement model for workplace boredom has a good fit to the data $(\mathrm{CFI}=0.97$; TLI $=0.95$; RMSEA $=0.06$; $\mathrm{SRMR}=0.03)$. This result supported $\mathrm{H}_{1}$. Table 2 presents the standardised factor loadings and variances explained of the individual items for the workplace boredom factor.

The results of the CFA showed that all items of workplace boredom had statistically significant factor loadings $(\lambda)$. The item with arguably the most face validity ('I feel bored at my job') had $48 \%$ of its variance explained by the latent workplace boredom variable. Furthermore, the items with the highest factor loading were item 3 ('During work time, I daydream'; $\lambda=0.73 ; \mathrm{SE}=0.03 ; p=0.001$ ), followed by item 6 ('At my work, there is not so much to do'; $\lambda=0.71 ; \mathrm{SE}=0.03 ; p=0.001$ ). These items also had the highest explained variance values $\left(R^{2}=0.53 ; 0.51\right)$. Conversely, the items with the lowest factor loadings were item 4 ('It seems as if my working day never ends'; $\lambda=0.22 ; \mathrm{SE}=0.05 ; p<0.001$ ) and item 1 ('At work, time goes by very slowly'; $\lambda=0.25$; SE $=0.05 ; p<0.001$ ). These items also had the lowest explained variance values at $5 \%\left(R^{2}=0.05\right)$ and $6 \%\left(R^{2}=0.06\right)$, respectively. Exploratory factor analysis (EFA) was also performed with the potential of one- to three-factor models, but only a one-factor model was able to converge - further evidence for the validity of the one-factor structure and in support of $\mathrm{H}_{1}$.

\section{Convergent validity: final measurement model fit statistics and correlations}

Models were initially tested with work engagement as a one-factor model (BIC $=36962.77)$ and two-factor model $(\mathrm{BIC}=37676.13)$. The one-factor model showed the best fit to the data and was therefore used in the final model. The final measurement model, which contained all of the study variables, showed the following fit statistics: $\mathrm{CFI}=0.91$; $\mathrm{TLI}=0.90 ; \mathrm{RMSEA}=0.07$; SRM $=0.07$. These values were considered acceptable and the interpretation of the correlation matrix was deemed appropriate.

Table 3 presents the correlation matrix for the latent variables with their respective Cronbach's alpha coefficient on the diagonal in brackets.

As is evident in Table 3, all constructs had acceptable internal consistency. Specifically, the alpha coefficient showed that workplace boredom had acceptable reliability $(\alpha=0.78)$, that is, the internal consistency was acceptable compared to the commonly accepted guidelines (Bland \& Altman, 1997). This result supported $\mathrm{H}_{2}$. The 'scale if item deleted' option showed that reliability could be slightly improved to 0.83 if item 4 was omitted from the factor. However, the analysis continued with all six items given the acceptable reliability in the first instance.

TABLE 2: Standardised factor loadings of the items for the latent workplace boredom variable.

\begin{tabular}{lcccc}
\hline Item text & Loading & SE & $p$ & $\boldsymbol{R}^{\mathbf{2}} \mathbf{( \% )}$ \\
\hline During work time, I daydream & 0.73 & 0.03 & $0.001 *$ & $0.53(53)$ \\
At my work, there is not so much to do & 0.71 & 0.03 & $0.001 *$ & $0.51(51)$ \\
I feel bored at my job & 0.69 & 0.03 & $0.001 *$ & $0.48(45)$ \\
I tend to do other things during my work & 0.62 & 0.04 & $0.001 *$ & $0.38(38)$ \\
At work, time goes by very slowly & 0.25 & 0.05 & $0.001 *$ & $0.06(6)$ \\
It seems as if my working day never ends & 0.22 & 0.05 & $0.001 *$ & $0.05(5)$ \\
\hline
\end{tabular}

${ }^{*} p<0.001 ; \mathrm{SE}$, standard error; $R^{2}$, variance explained in item.

TABLE 3: Correlation matrix for the latent variables.

\begin{tabular}{lcccc}
\hline Variables & $\mathbf{1}$ & $\mathbf{2}$ & $\mathbf{4}$ & $\mathbf{5}$ \\
\hline 1. Workplace boredom & $(0.78)$ & - & - & - \\
2. Work underload & $0.30 \dagger$ & $(0.77)$ & - & - \\
3. Work engagement & $-0.59 \dagger \dagger$ & -0.25 & $(0.91)$ & - \\
4. Organisational commitment & $-0.41 \dagger$ & -0.15 & $0.60 \dagger \dagger$ & $(0.83)$ \\
\hline
\end{tabular}

Notes: All correlations were statistically significant $(p<0.001)$; Cronbach's alpha on the diagonal in brackets; $\uparrow$, medium practical effect; $\uparrow \dagger$, large practical effect.

\begin{tabular}{|c|c|c|c|c|c|c|}
\hline Item & M & SD & Skewness & Kurtosis & Min value $(\%)$ & Max value $(\%)$ \\
\hline During work time, I daydream & 1.89 & 1.02 & 1.18 & 0.89 & 44.01 & 2.69 \\
\hline At my work, there is not so much to do & 1.77 & 1.01 & 1.46 & 1.58 & 51.66 & 2.70 \\
\hline I feel bored at my job & 2.12 & 1.14 & 0.76 & -0.30 & 35.40 & 2.69 \\
\hline I tend to do other things during my work & 2.13 & 0.94 & 0.77 & 0.44 & 26.03 & 2.07 \\
\hline At work, time goes by very slowly & 2.78 & 1.26 & 0.26 & -0.92 & 17.56 & 12.91 \\
\hline It seems as if my working day never ends & 2.95 & 1.18 & 0.13 & -0.86 & 11.13 & 12.16 \\
\hline
\end{tabular}

$\mathrm{M}$, mean; SD, standard deviation. 
Workplace boredom was statistically negatively correlated with all of the study variables, except with work underload, with which it was positively correlated $(r=0.30$; medium effect; supporting $\mathrm{H}_{3}$ ). Workplace boredom was negatively and significantly correlated with work engagement $(r=-0.59$; supporting $\left.\mathrm{H}_{4}\right)$ and organisational commitment $(r=-0.41$; supporting $\mathrm{H}_{5}$ ). Work engagement and organisational commitment correlated positively with a large practical effect $(r=0.60)$.

\section{Discriminant validity}

Sufficient evidence for discriminant validity was found for the workplace boredom construct. All variables had correlations with boredom that were below the set cut-off point (i.e. $r=0.85$; Brown, 2015). This was indeed the case with all variables; for example, the AVE of workplace boredom was $34 \%$, and for work engagement the AVE was 55\%. The shared variance between these two constructs was only $12 \%$.

\section{Predictive validity: A mediation model}

Figure 2 presents the results for the structural paths of the research model.

As is evident from Figure 2, work underload had a positive relation to workplace boredom $(\beta=0.30$; $\mathrm{SE}=0.05 ; p<0.001)$, which in turn constituted a negative predictor of work engagement $(\beta=-0.56 ; \mathrm{SE}=0.04 ; p<0.001)$ and organisational commitment $(\beta=-0.40$; SE $=0.05 ; p<0.001)$. The direct relationships from work underload to work engagement and organisational commitment were not significant. However, bootstrapping revealed that there was a significant indirect relationship from work underload to both work engagement $\left(-0.17 ; \mathrm{SE}=0.03 ; p=0.001\right.$; supporting $\left.\mathrm{H}_{6}\right)$ and organisational commitment $\left(-0.12 ; \mathrm{SE}=0.03 ; p=0.001\right.$; supporting $\left.\mathrm{H}_{7}\right)$ through workplace boredom - indicating an indirect-only mediating mechanism (cf. Zhao et al. 2010), synonymous to full mediation.

\section{Discussion}

\section{Main study results}

The aim of the current study was to validate a workplace boredom scale by investigating its factor structure, construct validity (convergent and discriminant validity) and

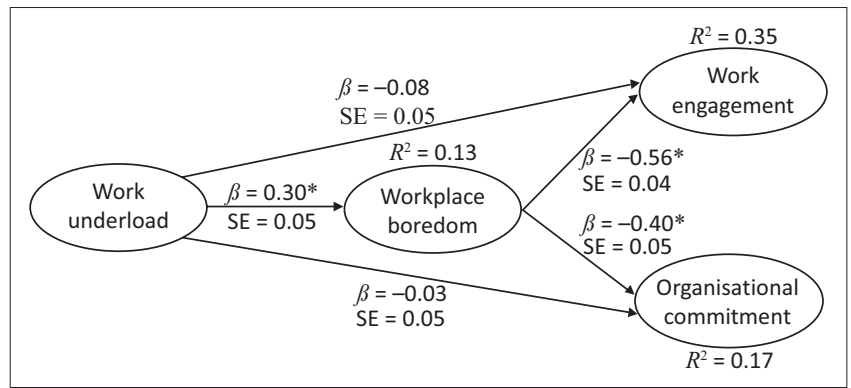

Notes: ${ }^{*}, p<0.001 ; \mathrm{SE}$, standard error.

FIGURE 2: Standardised estimates for the direct relationships of the structural model. predictive validity using the following variables: work underload and two organisational outcomes (i.e. work engagement and organisational commitment).

Firstly, this study sought to confirm that the workplace boredom scale has a one-factor structure. The CFA results established that the proposed one-factor measurement model for workplace boredom was indeed a good fit to the data and that the EFA resulted in a one-factor model. This is in line with the original study by Reijseger et al. (2012), providing evidence that workplace boredom should also be operationalised as a one-factor structure in South Africa. This result supported $\mathrm{H}_{1}$.

For the purpose of calculating the reliability of the constructs, Cronbach's alpha coefficients were used. All reliability values were above the threshold of 0.70 . Specifically, the workplace boredom construct attained an acceptable value $(\alpha=0.78)$, indicating that the construct had sufficient internal consistency. Correspondingly, Reijseger et al. (2012) reported a similar alpha reliability coefficient of 0.80 , and Harju et al. reported an alpha of 0.85 for the same scale. This result supported $\mathrm{H}_{2}$.

Next, convergent validity was investigated by establishing the correlation between workplace boredom and other constructs (Campbell \& Fiske, 1959). Correlation coefficients were investigated to confirm the degree of convergence between workplace boredom, work underload, work engagement and organisational commitment. In terms of $\mathrm{H}_{3}$, the results indicated a positive correlation between workplace boredom and work underload; therefore $\mathrm{H}_{3}$ was supported. According to Karasek (1979), employees in passive, unchallenging jobs are at risk of becoming bored at work, which is likely the case with employees who experience underload. Reijseger et al. (2012) also found that a lack of job demands is associated with workplace boredom. As expected, all outcomes were found to have a negative and practically significant relationship with workplace boredom. Specifically, the results indicated a negative significant correlation and regression from workplace boredom to work engagement, supporting $\mathrm{H}_{4}$. This finding is in line with the current literature. When employees experience boredom at work, it can be anticipated that their level of work engagement will decrease, as workplace boredom is a deactivating negative state, contrary to work engagement, which is described as an activating positive state (Schaufeli, 2012). Likewise, Reijseger et al. (2012) also found workplace boredom to be negatively related to work engagement.

Next, workplace boredom was found to be negatively practically and significantly correlated to organisational commitment. Supporting this finding, Watt and Hargis (2010) found a direct relationship between boredom proneness and job attitudes, such as organisational commitment and involvement. In addition, the findings by Reijseger et al. (2012) suggest that employees will experience more organisational commitment when experiencing less boredom. $\mathrm{H}_{5}$ was thus supported. 
For predictive validity, structural regression paths were added to the measurement model to determine whether workplace boredom is a predictor of work engagement and organisational commitment (Figure 1). The results indicated no direct relationships between work underload and work engagement or organisational commitment, but instead an indirect relationship was found between work underload and both work engagement and organisational commitment through workplace boredom. This finding indicated that workplace boredom mediated these relationships in an indirect-only mediation model (synonymous to full mediation) (see Zhao et al. 2010). These results supported $\mathrm{H}_{6}$ and $\mathrm{H}_{7}$, respectively. Therefore, work underload has a positive relationship to workplace boredom, and in turn the experience of workplace boredom might be detrimental to employee performance and to their commitment to the organisation.

\section{Practical implications}

The current study provides evidence for the validity and reliability of a workplace boredom measure for use in South African organisations. Organisations should measure workplace boredom and consider strategies to counter its negative effects on organisational outcomes, including work engagement and organisational commitment, as illustrated in the current study. Furthermore, it was found that work underload has a positive relationship with boredom, indicating that employees that have a low workload (who are under-challenged) will probably experience more boredom (and vice versa). It is however important to note that just increasing the workload of employees - without ensuring meaningful work - is not necessarily an apt strategy to tackle boredom at work (cf. Matthews et al. 2000). One potential avenue of recourse could be transformational leadership strategies, which have been shown by research to play an important role in enhancing meaningful work (Arnold, Turner, Barling, Kelloway \& McKee, 2007). Additionally, job redesign and job enrichment strategies can also be considered to enhance motivation by increasing meaning, learning and development as presented in a research review study (Parker, 2014).

\section{Limitations of the study}

The present research provided valuable findings. However, it is essential to highlight the limitations of the current study as well. Firstly, a cross-sectional design was utilised, which precludes any causal interpretation. A longitudinal study should therefore be conducted to investigate the assumed or hypothesised causal order (Taris \& Kompier, 2006). In addition, other variables such as burnout, work performance, sickness, absence and satisfaction with life should be included in future research on predictive validity.

These data were collected from organisations in only two sectors, the manufacturing sector and the logistics sector, so care should be taken not to generalise the findings to other contexts. Therefore, additional exploration is necessary in different economic sectors and occupations to examine the phenomenon of workplace boredom and its manifestations further. Generalisations should thus be made with caution.

Furthermore, employees with high demands or high workloads are also at risk of experiencing workplace boredom (Fisher, 1993). This is a vital piece of information, as redesigning the job to merely include higher demands will not suffice to eradicate workplace boredom. The assortment of possible antecedents for workplace boredom should therefore be broadened beyond workload (overload and under-load) to investigate other individual factors, such as personality. Moreover, it is important to consider job complexity and employee capabilities in their current positions as further confounding aspects in future workplace boredom research.

The study made use of a self-report questionnaire, which is often criticised for issues of measurement bias (Spector, 1994). Due to the nature of self-report questionnaires, the participant's perception and experience of a phenomenon are subjective. Methods to address this concern are limited (Salkind, 2009). However, self-report questionnaires are often utilised as they are considered a normal or natural method for exploring latent concepts such as workplace boredom (Podsakoff, MacKenzie, Lee \& Podsakoff, 2003). Daily diary studies could also be considered, which could ascertain day-level results on workplace boredom within and between employees. Qualitative interviews are also a possibility when utilising a mixed method research design to gain a more in-depth understanding of the experience of boredom at work.

\section{Conclusion}

This study presented evidence pertaining to the reliability and validity of a workplace boredom scale for use within the South African context. Specifically, workplace boredom was confirmed as a one-factor structure, an acceptable reliability coefficient was established and significant negative correlations and regressions were found among workplace boredom, organisational commitment and work engagement. Additionally, with the predictive validity mediation model, this study provides evidence for the full mediating role of workplace boredom between work underload and work engagement, organisational commitment. Managers should therefore not neglect workplace boredom, but consider strategies to effectively address the impact of boredom on organisational outcomes, which in turn would affect organisational success.

\section{Acknowledgements Competing interests}

The authors declare that they have no financial or personal relationships that may have inappropriately influenced them in writing this article. 


\section{Authors' contributions}

This publication is based on the master's dissertation of S.V.W. (North-West University). L.T.d.B. (North-West University) was the study leader of the project, acted as corresponding author and performed the statistical analyses. The first and second authors contributed equally to the publication version. J.P. (North-West University) was the assistant supervisor for the dissertation. W.S. (Utrecht University \& KU Leuven) acted as expert reviewer and provided important conceptual inputs on the publication.

\section{References}

Allen, N.J., \& Meyer, J.P. (1990). The measurement and antecedents of affective, continuance and normative commitment to the organization. Journal of Occupational Psychology, 63(1), 1-18. http://dx.doi.org/10.1111/j.2044-8325. 1990.tb00506.x

Arnold, K.A., Turner, N., Barling, J., Kelloway, E.K., \& McKee, M.C. (2007). Transformational leadership and psychological well-being: The mediating role of meaningful work. Journal of Occupational Health Psychology, 12(3), 193-203. http://dx.doi.org/10.1037/1076-8998.12.3.193

Baker, P.L. (1992). Bored and busy: Sociology of knowledge of clerical workers Sociological Perspectives, 35, 489-503. http://dx.doi.org/10.2307/1389331

Baumeister, R.F. (1991). Meanings of life. New York: Guildford.

Beehr, T.A., Walsh, J.T., \& Taber, T.D. (1976). Relationship of stress to individually and organisationally valued states: Higher order needs as a moderator. Journal of Applied Psychology, 61, 41-47. http://dx.doi.org/10.1037/0021-9010.61.1.41

Bland, J.M., \& Altman, D.G. (1997). Statistics notes: Cronbach's alpha. British Medical Journal, 314(7080), 572-573. http://dx.doi.org/10.1136/bmj.314.7080.572

Brown, T.A. (2015). Confirmatory factor analysis for applied research (2nd edn.). New York: Guilford Press.

Bruursema, K., Kessler, S.R., \& Spector, P.E. (2011). Bored employees misbehaving: The relationship between boredom and counterproductive work behavior as it is critical to the success of any business. Work \& Stress, 25(2), 93-107. http://dx.doi. org/10.1080/02678373.2011.596670

Campbell, D.T., \& Fiske, D.W. (1959). Convergent and discriminant validation by the multitrait-multimethod matrix. Psychological Bulletin, 56(2), 81-105. http://dx. doi.org/10.1037/h0046016

Cohen, J. (1988). Statistical power analysis for the behavioral sciences (rev. edn.). Orlando, FL: Academic Press.

Cudeck, R., \& Browne, M.W. (1993). Alternative ways of assessing model fit. In K.A. Bollen \& J. Scott Long (Eds.), Testing structural equation models (pp. 136-162). Newbury Park, CA: Sage.

Damrad-Frye, R., \& Laird, J.D. (1989). The experience of boredom: The role of selfperception of attention. Journal of Personality and Social Psychology, 24, 19-36. $\mathrm{http}: / / \mathrm{dx}$.doi.org/10.1037/0022-3514.57.2.315

De Vos, A.S., Strydom, H., Fouché, C.B., \& Delport, C.S.L. (2012). Research at grass roots: For the social sciences and human service professions (4th edn.). Pretoria: Van Schaik.

Du Plooy, G.M. (2002). Communication research: Techniques, methods and applications (2nd edn.). Cape Town: Juta.

Farmer, R., \& Sundberg, N.D. (1986). Boredom proneness: The development and correlates of a new scale. Journal of Personality Assessment, 50(1), 4-17. http:// dx.doi.org/10.1207/s15327752jpa5001_2

Fineman, S., \& Payne, R. (1981). Role stress: A methodological trap? Journal of Occupational Behavior, 2(1), 51-64. http://dx.doi.org/10.1002/job.4030020105

Fisher, C.D. (1993). Boredom at work: A neglected concept. Human Relations, 46(3), 395-417. http://dx.doi.org/10.1177/001872679304600305

Fornell, C., \& Larcker, D.F. (1981). Evaluating structural equation models with unobservable variables and measurement error. Journal of Marketing Research, 18, 39-50. http://dx.doi.org/10.2307/3151312

Foxcroft, C., \& Roodt, G. (2009). Introducing psychological assessment: In the South African context. Cape Town: Oxford University Press.

Game, A.M. (2007). Workplace boredom coping: Health, safety, and HR implications. Personnel Review, 36(5), 701-721. http://dx.doi.org/10.1108/00483480710774007

George, D., \& Mallery, P. (2010). SPSS for Windows step by step. A simple guide and reference (4th edn.). Boston, MA: Allyn and Bacon.

Government Gazette. (October 19, 1998). Republic of South Africa (Vol. 400, no. 19379). Cape Town.

Grubb, E.A. (1975). Assembly line boredom and individual differences in recreation participation. Journal of Leisure Research, 7, 256-269.

Hair, J.F., Black, W.C., Babin, B.J., \& Anderson, R.E. (2010). Multivariate data analysis (7th edn.). Englewood Cliffs, NJ: Prentice Hall.

Hamilton, J.A., Haier, R.J., \& Buchsbaum, M.S. (1984). Intrinsic enjoyment and boredom coping scales: Validation with personality, evoked potential and attention measures. Personality and Individual Differences, 5(2), 183-193. http:// dx.doi.org/10.1016/0191-8869(84)90050-3
Harju, L., Hakanen, J.J., \& Schaufeli, W.B. (2014). Job boredom and its correlates in 87 Finnish organizations Journal of Occupational and Environmental Medicine, 56(9), 911-918. http://dx.doi.org/10.1097/JOM.0000000000000248

Hellgren, J., Sjöberg, A., \& Sverke, M. (1997). Intention to quit: Effects of job satisfaction and job perceptions. In F. Avallone, J. Arnold, \& K. de Witte (Eds.), Feelings work in Europe (pp. 415-423). Milano: Guerini.

Hill, A.B., \& Perkins, R.E. (1985). Towards a model of boredom. British Journal of Psychology, 76, 235-240. http://dx.doi.org/10.1111/j.2044-8295.1985.tb01947.x

Karasek, R.A. (1979). Job demands, job decision latitude and mental strain: Implications for job redesign. Administrative Science Quarterly, 24, 285-308. http://dx.doi.org/10.2307/2392498

Kass, S.J., Vodanovich, S.J., \& Callender, A. (2001). State-trait boredom: Relationship to absenteeism, tenure, and job satisfaction. Journal of Business and Psychology, 16, 317-327. http://dx.doi.org/10.1023/A:1011121503118

Kass, S.J., Wallace, C., \& Vodanovich, S.J. (2003). Boredom proneness and sleep disorder as predictors of adult attention deficit scores. Journal of Attention disorder as predictors of adult attention deficit scores. Journal of Atter
Disorders, 7(2), 83-91. http://dx.doi.org/10.1177/108705470300700202

Kim, S.W., Price, J.L., Mueller, C.W., \& Watson, T.W. (1996). The determinants of career intent among physicians at a US Air Force hospital. Human Relations, 49(7), 947-976. http://dx.doi.org/10.1177/001872679604900704

Langelaan, S., Bakker, A.B., Van Doornen, L.J.P., \& Schaufeli, W.B. (2006). Burnout and work engagement: Do individual differences make a difference? Personality and Individual Differences, 40, 521-532. http://dx.doi.org/10.1016/j.paid.2005.07.009

Larson, L.L. (2004). Internal auditors and job stress. Managerial Auditing Journal, 19(9), 1119-1130. http://dx.doi.org/10.1108/02686900410562768

Lazarus, R.S. (1991). Progress on a cognitive-motivational-relational theory of emotion American Psychologist, 46, 819-834. http://dx.doi.org/10.1037/0003-066X.46.8.819

Lee, T.W. (1986). Toward the development and validation of a measure of job boredom. Manhattan College Journal of Business, 15, 22-28.

Loukidou, L., Loan-Clarke, J., \& Daniels, K. (2009). Boredom in the workplace: More than monotonous tasks. International Journal of Management Reviews, 11(4), 381-405. http://dx.doi.org/10.1111/j.1468-2370.2009.00267.x

Markos, S., \& Sridevi, M.S. (2010). Employee engagement: The key to improving performance. International Journal of Business and Management, 5(12), 89-95.

Martin, M., Sadlo, G., \& Stew, G. (2006). The phenomenon of boredom. Qualitative Research in Psychology, 3(3), 193-211. http://dx.doi.org/10.1191/ 1478088706 qrp066oa

Matthews, K.A., Räikkönen, K., Everson, S.A., Flory, J.D., Marco, C.A., Ownes, J.F., et al. (2000). Do the daily experiences of healthy men and women vary according to
occupational prestige and work strain? Psychosomatic Medicine, 62, 346-353. occupational prestige and work strain? Psychosomatic
$\mathrm{http}: / / \mathrm{dx}$.doi.org/10.1097/00006842-200005000-00008

Meyer, J.P., Allen, N.J., \& Smith, C.A. (1993). Commitment to organizations and occupations: Extension and test of a three-component conceptualization. Journal of occupations: Extension and test of a three-component conceptualization. Journal of
Applied Psychology, 78(4), 538-551. http://dx.doi.org/10.1037/0021-9010.78.4.538

Meyer, J.P., Stanley, D.J., Herscovitch, L., \& Topolnytsky, L. (2002). Affective, continuance, and normative commitment to the organization: A meta-analysis of antecedents, correlates, and consequences. Journal of Vocational Behavior, 61(1), 20-52. http://dx.doi.org/10.1006/jvbe.2001.1842

Meyer, M. (2012). Managing human resource development: A strategic learning approach. Durban: LexisNexis.

Mikulas, W., \& Vodanovich, S. (1993). The essence of boredom. The Psychological Record, 43, 3-12.

Muthén, L.K., \& Muthén, B.O. (2014). Mplus user's guide (7th edn.). Los Angeles, CA: Muthén \& Muthén.

O'Dwyer, L.M., \& Bernauer, J.A. (2014). Quantitative research for the qualitative researcher. Thousand Oaks, CA: Sage.

Parker, S.K. (2014). Beyond motivation: Job and work design for development, health, ambidexterity, and more. Annual Review of Psychology, 65, 661-691. http://dx. doi.org/10.1146/annurev-psych-010213-115208

Pienaar, J., Sieberhagen, C.F., \& Mostert, K. (2007). Investigating turnover intentions by role overload, job satisfaction and social support moderation. SA Journal of Industrial Psychology, 33(2), 62-67. http://dx.doi.org/10.4102/sajip.v33i2.378

Podsakoff, P.M., MacKenzie, S.B., Lee, J.Y., \& Podsakoff, N.P. (2003). Common method biases in behavioral research: A critical review of the literature and recommended remedies. Journal of Applied Psychology, 88, 879-903. http://dx.doi.org/ 10.1037/0021-9010.88.5.879

Reijseger, G., Schaufeli W.B., Peeters, M.C.W., Taris, T.W., Van Beek, I., \& Ouweneel, E. (2012). Watching the paint dry at work: Psychometric examination of the Dutch Boredom Scale. Anxiety, Stress, \& Coping, 26(5), 508-525. http://dx.doi.org/10.1 080/10615806.2012.720676

Rodrik, D. (2008). Understanding South Africa's economic puzzles. Economics of Transition, 16(4), 769-779. http://dx.doi.org/10.1111/j.1468-0351.2008.00343.x

Rucker, D.D., Preacher, K.J., Tormala, Z.L., \& Petty, R.E. (2011). Mediation analysis in social psychology: Current practices and new recommendations. Social and Personality Psychology Compass, 5(6), 359-371. http://dx.doi.org/10.1111/ j.1751-9004.2011.00355.x

Salkind, N.J. (2009). Exploring research (7th edn.). Upper Saddle River, NJ: Pearson.

Schaufeli, W.B. (2012). Work engagement: What do we know and where do we go? Romanian Journal of Applied Psychology, 14(1), 3-10.

Schaufeli, W.B., Bakker, A.B., \& Salanova, M. (2006). The measurement of work engagement with a short questionnaire: A cross-national study. Educational and Psychological Measurement, 66(4), 701-716. http://dx.doi.org/10.1177/ 0013164405282471 
Schaufeli, W.B., \& Salanova, M. (2014). Burnout, boredom and engagement at the workplace. In M. Peeters, J. de Jonge, \& T. Taris (Eds.), People at work:
An introduction to contemporary work psychology (pp. 293-320). Chichester: Wiley-Blackwell.

Schaufeli, W.B., Salanova, M., Gonzalez-Romá, V., \& Bakker, A.B. (2002). The measurement of engagement and burnout: A confirmative analytic approach. Journal of Happiness Studies, 3,71-92. http://dx.doi.org/10.1023/A:1015630930326

Schubert, D.S. (1977). Increase of creativity by prior response to a problem. Journal of General Psychology, 96(2), 323-324. http://dx.doi.org/10.1080/00221309.1977.9 920831

Shackleton, V.J. (1981). Boredom and repetitive work: A review. Personnel Review, 10 30-36. http://dx.doi.org/10.1108/eb055445

Smith, R.P. (1981). Boredom: A review. Human Factors: The Journal of the Human Factors and Ergonomics Society, 23(3), 329-340.

Sohail, N., Ahmad, B., Tanveer, Y., \& Tariq, H. (2012). Workplace boredom among university faculty members in Pakistan. Interdisciplinary Journal of Contemporary Research in Business, 3(10), 919-925.

Spector, P.E. (1994). Using self-report questionnaires in OB research: A comment on the use of a controversial method. Journal of Organizational Behavior, 15, 385392. http://dx.doi.org/10.1002/job.4030150503

Spector, P.E., \& Jex, S.M. (1998). Development of four self-report measures of job stressors and strain: Interpersonal conflict at work scale, organizational constraints scale, quantitative workload inventory, and physical symptoms inventory. Journal of Occupational Health Psychology, 3(4), 356-367. http://dx.doi.org/10.1037/ 1076-8998.3.4.356

Storm, K., \& Rothmann, S. (2003). A psychometric analysis of the Utrecht Work Engagement Scale in the South African Police Service. SA Journal of Industrial Psychology, 29(4), 62-70. http://dx.doi.org/10.4102/sajip.v29i4.129

Struwig, F.W., \& Stead, G.B. (2001). Planning, designing and reporting research. Cape Town: Pearson Education South Africa.

Sundberg, N.D., \& Staat, K. (1992). Boredom and culture. Paper presented at the Emotion and Culture Conference, Eugene, OR.

Taris, T.W., \& Kompier, M.A.J. (2006). Games researchers play: Extreme-groups analysis and mediation analysis in longitudinal, occupational, and health research Scandinavian Journal of Work, Environment, \& Health, 32, 463-472. http://dx.do org/10.5271/sjweh.1051
Van de Schoot, R., Lugtig, P., \& Hox, J. (2012). A checklist for testing measurement invariance. European Journal of Developmental Psychology, 9(4), 486-492. http:// dx.doi.org/10.1080/17405629.2012.686740

Van Tilburg, W.A., \& Igou, E.R. (2012). On boredom: Lack of challenge and meaning as distinct boredom experiences. Motivation and Emotion, 36(2), 181-194. http:// dx.doi.org/10.1007/s11031-011-9234-9

Vodanovich, S.J., Wallace, J.C., \& Kass, S.J. (2005). A confirmatory approach to the factor structure of the Boredom Proneness Scale: Evidence for a two-factor short form. Journal of Personality Assessment, 85(3), 295-303. http://dx.doi.org/ 10.1207/s15327752jpa8503_05

Wallace, J.C., Vodanovich, S.J., \& Restino, R. (2003). Predicting cognitive failures from boredom proneness and daytime sleepiness scores: An investigation within military and undergraduate samples. Personality and Individual Differences, 34 635-644. http://dx.doi.org/10.1016/S0191-8869(02)00050-8

Warr, P. (1990). The measurement of well-being and other aspects of mental health Journal of Occupational Psychology, 63(3), 193-210. http://dx.doi.org/10.1111/ j.2044-8325.1990.tb00521.x

Warr, P., \& Inceoglu, I. (2012). Job engagement, job satisfaction, and contrasting associations with person-job fit. Journal of Occupational Health Psychology, 17(2), 129-138. http://dx.doi.org/10.1037/a0026859

Watt, J.D., \& Hargis, M.B. (2010). Boredom proneness: Its relationship with subjective underemployment, perceived organizational support and job performance. Journal of Business Psychology, 25, 163-174. http://dx.doi.org/10.1007/s10869009-9138-9

Weiss, H.M., \& Cropanzano, R. (1996). Affective events theory: A theoretical discussion of the structure, causes and consequences of affective experiences at work. In B.M. Staw \& L.L. Cummings (Eds.), Research in organizational behavior: An annual series of analytical essays and critical reviews (pp. 1-74). Greenwich, CT: JAI Press.

Westen, D., \& Rosenthal, R. (2003). Quantifying construct validity: Two simple measures. Journal of Personality and Social Psychology, 84, 608-618. http:// dx.doi.org/10.1037/0022-3514.84.3.608

Whiteoak, J.W. (2014). Predicting boredom-coping at work. Personnel Review, 43(5), 741-763. http://dx.doi.org/10.1108/PR-09-2012-0161

Zhao, X., Lynch, J.G., \& Chen, Q. (2010). Reconsidering Baron and Kenny: Myths and truths about mediation analysis. Journal of Consumer Research, 37, 197-206. http://dx.doi.org/10.1086/65125 